\title{
The Development of Child Welfare Programs
}

\author{
By Arthur Dunham
}

$I^{\mathrm{N}}$ N THE section of the Social Security Act which provides for child welfare services is an interesting phrase. The act provides:

The amount so allotted shall be expended for payment of part of the cost of district, county, or other local child-welfare services in areas predominantly rural, and for developing state services for the encouragement and assistance of adequate methods of community child-welfare organization in areas predominantly rural and other areas of special need. ${ }^{1}$

This is probably the first instance of the use of the phrase "community childwelfare organization" in American law. The appearance of this phrase in the most far-reaching public welfare statute in the history of the United States is indicative of an important trend in child welfare in this country. There is an increasing tendency to emphasize the community organization aspects of child welfare and to stress child welfare programs in contrast with mere unrelated individual services.

\section{Community ORganization aNd Program Planning}

The activities, during 1939, of a number of local study committees operating under the auspices of Section III, Community Organization, of the National Conference of Social Work, led to a report which, in spite of its preliminary and tentative quality, is the most useful statement we have yet had regarding the nature and characteristics of community organization. ${ }^{2}$

\footnotetext{
1 Social Security Act, Title V, Part 3, Section 521 (a).

2 "The Field of Community Organization," Proceedings, National Conference of Social Work, 1939 (655 pp. New York: Columbia University Press, 1939), pp. 495-511.
}

One of the most important contributions of this report was a statement of the "general aim" and the "secondary objectives" of community organization. The report suggested

that the general aim of community organization is to bring about and maintain a progressively more effective adjustment between social-welfare resources and socialwelfare needs. This implies that community organization is concerned with (a) the discovery and definition of needs; (b) the elimination and prevention of social needs and disabilities, so far as possible; and (c) the articulation of resources and needs, and the constant readjustment of resources in order better to meet changing needs. $^{3}$

The report goes on to set forth six "secondary objectives" for community organization:

1. To secure and maintain an adequate factual basis for sound planning and action.

2. To initiate, develop, and modify welfare programs and services, in the interest of attaining a better adjustment between resources and needs.

3. To improve standards of social work and to increase the effectiveness of individual agencies.

4. To improve and facilitate interrelationships, and to promote co-ordination, between organizations, groups, and individuals concerned with social-welfare programs and services.

5. To develop a better public understanding of welfare problems and needs, and social-work objectives, programs, and methods.

6. To develop public support of, and public participation in, social-welfare activities. Financial support includes income from tax funds, voluntary contributions, and other sources. ${ }^{4}$

${ }^{3}$ Ibid., p. 500.

4 Ibid. 


\section{Community Organization and Child Welfare}

Now community organization operates not in a vacuum but in reference to specific functional fields of social welfare-child welfare, family welfare and relief, health, recreation and leisuretime activities, and so on. Moreover, it is clear that each of these "secondary objectives" of community organization has direct and vital application to the field of child welfare. A factual basis is the only sound basis for planning and action regarding services for children. Initiating, developing, and modifying child welfare programs have been exemplified in scores of instances: visiting teacher services, child guidance clinics, and new public services have been initiated; small beginnings have developed into extensive services; child caring organizations have in many instances completely transformed their programs, as when a child caring institution has become a diagnostic center or foster-family placing agency, two child caring agencies have merged, a state public school has become a state child-placing agency, and so on. The improvement of child welfare standards and the development of better teamwork have been constant concerns of the United States Children's Bureau, the Child Welfare League of America, state departments of welfare, councils of social agencies, and many other national, state, and local bodies. Finally, child welfare has shared with the other divisions of the field of social work the necessity of interpreting its needs, problems, and aims, and of enlisting something resembling adequate public support and participation.

Obviously, these six objectives of community organization cannot be thought of as separate and distinct goals. On the contrary, the processes of discovery, planning, initiation, main- tenance, development, modification, and co-ordination, which are implied in these objectives, are inextricably intertwined. Moreover, an unspoken assumption underlies all these objectives. We may follow one or the other of these objectives in respect to child welfare, at a particular time, in a particular place, under particular circumstances; but if we add all these objectives together, and apply them to the total child welfare problems and forces of a community, the result will be a community child welfare program.

What are the characteristics of a child welfare program for a community, a state, or other area? From one standpoint a program is a plan-not a theoretical plan remote from actualities, but a practical, dynamic, plan of action, focused upon living realities. In respect to social welfare planning, Neva R. Deardorff has written:

... planning implies that there must be growing clarity as to what social welfare programs will undertake to do in terms of definite activities; how much of each given activity is to be carried on at a given time; how it is to be done, that is, the method to be applied; how well it is to be done, that is, quality and expertness in the application of method; and how it is to be supported, and that these must all be thought of together. ${ }^{5}$

A program may be more than a plan, because some of the program or all of it may be actually in operation, and not merely proposed as "action in the future." Perhaps a program might best be described as a set of related activities or plans, or both, having a common objective. Thus the general objective of

${ }^{5}$ Neva R. Deardorff, "Areas of Responsibility of Voluntary Social Work during Period of Changing Local and National Governmental Programs," Proceedings, National Conference of Social Work, 1936 (655 pp. Chicago: University fo Chicago Press, 1936), pp. 316-17. 
a community child welfare program might be to provide the greatest possible opportunities for wholesome and abundant living for all the children of the community.

A program, or at any rate an effective program, implies a unified, integrated, and comprehensive whole; it implies balance, co-ordination, competent performance, and the avoidance of both "overlapping and overlooking."

If this is the nature of a program, what are some of the major approaches to the building of national, state, and local child welfare programs? More especially, which of these approaches have been important during the last ten years in respect to "children in need of special care"-particularly dependent and neglected children, children with behavior problems, and children born out of wedlock?

\section{Child Welfare Services under the Social Security Act}

The most impressive child welfare program development during the past ten years was the passage of the Social Security Act. The act marked a long step forward in the history of care of dependent children in their own homes by greatly expanding the traditional mothers' aid and by establishing aid to dependent children as a Federally aided category of public assistance. The establishment and initiation of this service was a matter of program development; carrying on the service after it is initiated is a case work job.

The Social Security Act established also Federal aid to the states for the development of maternal and child health services, services for crippled children, and child welfare services. These three types of child welfare services exemplify a program or communityorganization approach; the Federal grants are not on a case-by-case basis, as with aid to dependent children, but on the basis of aiding in the development of total state and local programs.

The history of the development of rural child welfare services, in particular, during the past four years, is a mine of rich material on the subject of community organization or program development in the public welfare field. Among the methods which have been used, exclusive of actual case work services, are the following: organization of local child welfare units and of state and local advisory committees; field service and consultation service from the state agency to local child welfare units and local officials; local demonstrations of child welfare services; a "mobile unit" for demonstration in and assistance to counties; studies and surveys of various sorts, to form a basis for sound planning and action; development of services for foster family placing, child guidance, and so forth; assistance in developing recreational projects and facilities; consultation and assistance to child caring organizations, leading to modifications of program or improvement in standards; development of library facilities for those concerned in child welfare programs; development of plans for better training of child welfare workers; education and interpretation; and co-ordination of child welfare services with other welfare programs. ${ }^{6}$

The diversity of the methods used illustrates particularly the flexibility of the program as a whole, the imaginative

${ }^{6}$ Child Welfare Services in Rural Areas: Excerpts from State Progress Reports, Six Months Ended December 31, 1937 (mimeographed, 187 pp., "Not available for general distribution"), Washington: U. S. Children's Bureau, 1938. For a record of the child welfare services in one county, see Grace A. Browning, "A Community Record from a Rural County," Social Service Review, Vol. XIV, No. 2 (June 1940), pp. 317-46. A report of child welfare services in the state of Oregon is contained in Child Welfare Services under the Social Security Act (40 pp.), New York: Child Welfare League of America, 1940. 
and resourceful leadership, and the wide range of possible approaches in developing public programs for children.

\section{National Agencies and Movements}

The services of national welfare agencies, public and private, have been among the most important forces in program building. Since 1912 the United States Children's Bureau has served as an expression of the concern of the Federal Government for the child. Throughout its history the Bureau has laid emphasis upon research, education, consultation, and co-operation; and its long series of publications form the backlog for the child welfare literature of the United States. The Bureau has had special administrative responsibilities for limited times, under the first Federal child labor law and the Federal Maternity and Infancy Act, and it is now the Federal agency for administering grants-in-aid under the Social Security Act for maternal and child health services, services for crippled children, and child welfare services. $^{7}$

In the private field, the Child Welfare League of America has performed unique services in making community child welfare surveys and studies of individual organizations, giving consultative field service, producing and publishing technical literature, holding regional conferences, and in many other ways seeking to raise standards of practice in the children's field.

Other national welfare agencies too numerous to mention touch the field of child welfare, either on the side of leisure-time activities or otherwise. The American Youth Commission is seeking

${ }^{7}$ See U. S. Department of Labor, Children's Bureau, The Children's Bureau: Yesterday, Today, and Tomorrow (57 pp.), Washington: Government Printing Office, 1937. See also annual reports of the Chief of the Children's Bureau. to assist in the building of an adequate educational and social program for youth. ${ }^{8}$ In the realm of civic agencies, the American Legion, through its Child Welfare Committee and co-operating committees, has issued a significant publication looking toward the development of a program for the prevention and treatment of juvenile delinquency. ${ }^{9}$

The four White House Conferences on child welfare have played a unique part in the development of child welfare programs. The pronouncements of these conferences, from 1909 to 1940, have afforded a series of "platforms" for child welfare agencies and workers; the conferences have emphasized and dramatized the Nation's concern for its children; and the publications of the conferences have contained not only statements of objectives, plans, and standards but also a vast amount of invaluable factual and interpretative material.

\section{State Agencies}

On the state level, two types of public agencies have played a leading part in the development of children's programs. Officially appointed child welfare commissions (earlier called children's code commissions) to study and recommend revisions in the laws relating to children were authorized in thirty-four states during the period 1911-31.10 At least two states-Illinois and Indiana--have had general child welfare commissions or committees in operation since 1931, and several other states have created

${ }^{8}$ M. M. Chambers, "Youth Programs," Social Work Year Book, 1939 (730 pp. New York: Russell Sage Foundation, 1939), pp. 490-92.

o Our Children's Future: A Practical Program for the Prevention and Treatment of Juvenile Delinquency (44 pp.), American Legion, National Headquarters, Indianapolis, 4th edition, no date.

${ }^{10}$ Grace Abbott, "Child Welfare Commissions," Social Work Year Book, 1933, p. 73 and footnote. 
commissions or committees on juvenile delinquency. In still other states unofficial committees are at work on child welfare problems and child welfare legislation.

Taken as a group, the child welfare commissions have performed an important function in reviewing the child welfare laws of the respective states and in considering these laws as a related whole. Their reports contain an important body of facts and considered op:nions as to child welfare legislation and the planning of state programs for children. The nearest parallel to the work of the children's commissions in the social welfare field is found in the state public welfare reorganization commissions of 1935 and the years following. In the main, the attention of these commissions has been focused upon general public welfare organization and public assistance; but many of them have been concerned to varying degrees, also, with certain aspects of child welfare.

The state department of welfare, or similar agency, is often in a key position to promote sound programs and standards of child welfare. The department is usually the state agency for administering child welfare services under the Social Security Act; and it may carry on "community organization" services in behalf of children through such methods as field service to local public agencies, inspection and licensing of private child caring organizations, studies of child welfare conditions and resources, holding of conferences, preparation and publication of educational material, and consultation and liaison service. ${ }^{11}$

11 For a statement of the general functions of state welfare departments, see Marietta Stevenson and Alice MacDonald, State and Local Public Welfare Agencies: An Organizational and Functional Analysis of State and Local Agencies Administering Public Welfare Functions (mimeographed, 109 pp.), Chicago: American Public Welfare Association, 1939. The best and almost the only available dis-
In the field of private endeavor the state conference of social work performs an educational function for child welfare as for other fields of social work, through its conference sessions and sometimes through short study courses; and in some instances the conference has been active in promoting legislation relating to child welfare and other subjects.

A few states have state-wide citizens' organizations, like the State Charities Aid Association of New York and the Public Charities Association of Pennsylvania, or specialized program-planning agencies such as the Children's Fund of Michigan and state associations for crippled children.

The county child welfare committees organized by the State Charities Aid Association have played a leading part in developing co-operation between public and private agencies and in building public child welfare services in New York State; ${ }^{12}$ and these committees laid a foundation for the expanded county committees on public welfare which are now being organized by the Association. In Pennsylvania the Child Welfare Division of the Public Charities Association gave leadership in a unique co-operative state-wide project for the planning of a Ten Year Program of

cussion of community organization activities of state welfare departments is to be found in "Educational Publicity for Promoting Social Work Programs," White House Conference on Child Health and Protection (1930), Organization for the Care of Handicapped Children (365 pp. New York: Century, 1932), pp. 209-44.

12 H. Ida Curry, "County Organization for Child-Welfare Work in New York State by the New York State Charities Aid Association," County Organization for Child Care and Protection, U. S. Children's Bureau Publication No. 107 (173 pp. Washington: Government Printing Office, 1922), pp. 93-108.

White House Conference on Child Health and Protection, Organization for the Care of Handicapped Children, 119-21. 
Child Welfare for Pennsylvania. This project involved the participation of more than a thousand individuals, and it included work by county discussion groups, state-wide planning and drafting committees, and a state-wide conference representing the public and private child welfare forces of the State. ${ }^{18}$

\section{LOCAL AGENCIES}

Both state and local child placing agencies, although they are primarily concerned with case work services, often play an important part also in community organization for child welfare and in the initiation and development of child welfare programs. A state children's aid society, for example, may develop county branches with child welfare programs for those counties; or a city child welfare agency may maintain a special department or special worker to do "conditions work"- that is, to make a community organization approach to the adjustment of community conditions which adversely affect the welfare of children.

In the public field, the integrated city or county department of public welfare or the local public child welfare agency may perform a community organization function as well as a case work function. Much of the significance of the early county welfare departments was their integration of several different public services; and for the most part these early departments had a child welfare focus rather than a public assistance focus, as is usually the case with the modern local public welfare departments. ${ }^{14}$

\footnotetext{
13 Public Charities Association of Pennsylvania, Pennsylvania's Ten Year Program for Children, 1930-1940 (unpaged), Philadelphia, 1931; Arthur Dunham, "Pennsylvania Thinks It Through," Survey Midmonthly, Vol. LXV, No. 8 (Jan. 15, 1931), pp. 424-25.

14 Mary Ruth Colby, The County as an Administrative Unit for Social Work, U. S. Chil-
}

The council of social agencies, which is often linked up with a community chest, is usually thought of as the central agency for social welfare planning in a local community. Three hundred and six councils or similar bodies are listed in a recent directory of Community Chests and Councils. ${ }^{15}$ The council, particularly in the larger community, is likely to have a division or department on child welfare or perhaps family and child welfare or case work. In the large city council this division will be likely to have at least one professional worker who is expected to combine a technical knowledge of the content of the field of child welfare with skill in community organization.

The Pittsburgh Social Study reported that the children's division of the Pittsburgh Federation of Social Agencies had a full-time secretary and a membership of sixty-eight agencies. Among the activities of the division were

the development of institutes on problems of child behavior attended by members of boards of directors and staffs of agencies; conferences with staff and committees to confer on problems arising in the institutional care of children; service to public departments in assisting to develop standards of personnel and service. ${ }^{18}$

Other council activities relating to child welfare in various cities would include studies and surveys of problems, of groups of agencies, and sometimes of individual agencies; divisional and committee meetings for discussion and selfeducation; group action in the formula-

dren's Bureau Publication No. 224 (48 pp.), Washington: Government Printing Office, 1933.

${ }^{15}$ Community Chests and Councils, What Councils of Social Agencies Do (57 pp. New York, 1939), p. 1.

${ }^{16}$ Philip Klein and collaborators, A Social Study of Pittsburgh (958 pp. New York: Columbia University Press, 1938), p. 410. 
tion of standards; consultation and help to individual agencies, on request; and the co-operative development of plans for new or reorganized child welfare programs. ${ }^{17}$

In so far as planning involves financing of private agencies supported by the community chest (and usually any farreaching plans have financial implications), matters relating to child welfare programs are closely connected with the process of budgeting by the community chest or the council as the agent of the chest.

Within recent years local "co-ordinating councils" have been organized in many American communities. They are concerned primarily with the prevention of juvenile delinquency, but sometimes they extend their purposes to cover wider areas of interest. ${ }^{18}$

17 Illustrations of some of these activities will be found in What Councils of Social Agencies Do, op. cit.

${ }^{18}$ Clarence King, "Councils in Social Work," Social Work Year Book, 1939, p. 100.

Our Children's Future, op. cit.
VIEWEd AS a Whole

The agencies and methods which have been mentioned are merely illustrative of the process of community organization for child welfare. Taken as a whole, they suggest the importance of and the opportunities for the development of integrated programs of child welfare on local, state, and national levels. Programs for children cannot be either blueprints or mechanisms; they must have within them the spirit of life and growth and adventure. The measure of all such programs is in their service to actual children. Child welfare programs are to be judged in terms of the degree to which they make child life more wholesome, more abundant, more happy, more rich in terms of health, education, work, play, and emotional, aesthetic, and spiritual development. Judged by this standard, the building of child welfare programs calls for the highest skills that we have, and presents one of the most challenging and rewarding tasks in the realm of social statesmanship.

Arthur Dunham is professor of community organization in the graduate Curriculum in Social Work of the University of Michigan. He has served as a member of the research staff of the Michigan Welfare and Relief Study Commission, secretary of the Family and Child Welfare Division of the Public Charities Association of Pennsylvania, field director of the Pennsylvania State Emergency Relief Board, director of the Pittsburgh Child Welfare Study, and director of special studies of the Family Welfare Association of America. He is the author of monographs and articles on community organization, child welfare, public welfare, and other aspects of social work. 